\title{
PENGARUH MODEL PEMBELAJARAN CORE TERHADAP PENGUASAAN KONSEP FISIKA PESERTA DIDIK KELAS XI MAN LOMBOK BARAT
}

\section{THE INFLUENCE OF CORE LEARNING MODEL THROUGH PHYSICS CONCEPT MASTERY OF XI STUDENTS IN MAN LOMBOK BARAT}

\author{
Mukarramah Mukarramah, Ni Nyoman Sri Putu Verawati, Ahmad Harjono \\ Program Studi Pendidikan Fisika, Jurusan Pendidikan MIPA, FKIP, Universitas Mataram \\ Jalan Majapahit No 62 Mataram \\ Email:veyra@unram.ac.id
}

Diterima: 18 Januari 2019. Disetujui: 02 Maret 2019. Dipublikasikan: 30 September 2019

\begin{abstract}
Abstrak:Penelitian ini bertujuan untuk mengetahui pengaruh model pembelajaran CORE terhadap penguasaan konsep fisika peserta didik kelas XI MAN Lombok Barat. Jenis penelitian ini adalah kuasi eksperimen dengan desain penelitian non-equivalent control group design. Populasi penelitian ini adalah seluruh peserta didik kelas XI MIAMAN Lombok Barat dengan teknik pengambilan sampel menggunakan sampling jenuh. Terdapat dua sampel yaitu kelas XI MIA 2 sebagai kelas eksperimen dan kelas XI MIA 1 sebagai kelas kontrol. Kelas eksperimen diberikan perlakuan dengan menggunakan model pembelajaran CORE, sedangkan kelas kontrol diberiperlakuan menggunakan model pembelajaran konvensional. Data penguasaan konsep diperoleh dengan menggunakan tes pilihan ganda beralasan berjumlah 25 soal dan dianalisis menggunakan uji-t polled varians. Hipotesis penelitian menunjukkan bahwa $t_{\text {hitung }}>t_{\text {tabel }}(2,355>2,021)$ pada taraf signifikan $5 \%$ yang berarti bahwa $\mathrm{H}_{\mathrm{o}}$ ditolak dan $\mathrm{H}_{\mathrm{a}}$ diterima. Berdasarkan hasil penelitian, dapat disimpulkan bahwa terdapat pengaruh model pembelajaran CORE terhadap penguasaan konsep fisika peserta didik kelas XI MAN Lombok Barat.
\end{abstract}

Kata Kunci: Model Pembelajaran CORE, PenguasaanKonsep.

\begin{abstract}
This research is aimed to discover the influence of CORE learning model through physics concept mastery of XI students in MAN Lombok Barat. This research was a quasi-experimental study with non-equivalent control group design. The population in this research was the whole students of XI MIA in MAN Lombok Barat and technique to pick a sample was used Saturation sampling. There were two samples in this research, such us XI MIA 2 class as the experimental group and XI MIA 1 class as the controlling group. The experimental group was treated using CORE learning model, while the controlling group was treated using conventional learning model. The data of concept mastery were gained by using reasonable multiple choices test which had 25 questions and analyzed by using $t$-test polled varians. The hypothesis showed that $t_{\text {count }}>t_{\text {table }}(2,355>2,021)$ in $5 \%$ significant standard which means that $\mathrm{H}_{0}$ is being rejected and $\mathrm{H}_{\mathrm{a}}$ is accepted. According to the research findings, it can be concluded that there was a significant influenced of CORE learning model through physics concept mastery of XI students in MAN Lombok Barat.
\end{abstract}

Keywords: CORE Learning Model, Concept Mastery

\section{PENDAHULUAN}

Pelajaran fisika adalah pelajaran yang mengajarkan berbagai pengetahuan yang dapat mengembangkan daya nalar dan analisa, sehingga hampir semua persoalan yang berkaitan dengan alam dapat dimengerti melalui pelajaran fisika, untuk dapat mengerti fisika secara luas, maka harus dimulai dengan kemampuan pemahaman dan penguasaan konsep dasar yang ada pada pelajaran fisika. Penguasaan konsep fisika sangat diperlukan peserta didik untuk menjelaskan berbagai fenomena alam dan memecahkan masalah teknologi di sekitar mereka. Selain itu, fisika juga mendidik peserta didik memiliki sikap intelektual dan religius dalam kehidupan sehari-hari.

Permasalahan yang sama terjadi pada pembelajaran fisika. Fisika sebagai bagian dari sains mengkaji pengetahuan mengenai gejala-gejala atau fenomena yang terjadi di alam. Fisika berisi kumpulan fakta-fakta, konsep-konsep atau prinsiprinsip tentang fenomena-fenomena alam yang selanjutnya akan diterapkan dalam kehidupan sehari-hari. Hal ini menjadikan fisika sebagai mata pelajaran yang sangat dibutuhkan. Kebutuhan ini berupa kebutuhan manusia untuk memecahkan masalah, di mana manusia merupakan mahluk hidup yang memiliki rasa keingintahuan tinggi. Keingintahuan ini menyebabkan manusia tidak puas dan cenderung merasa bosan jika yang dilakukannya hanya mendengar tanpa melihat sendiri peristiwa sebenarnya. Pembelajaran di sekolah tidak memungkinkan untuk menunjukkan semua peristiwa secara langsung dan nyata, misalnya pada peristiwa tumbukan antara sebuah motor dengan sebuah mobil. Banyak juga konsep-konsep maupun prinsip-prinsip fisika yang bersifat abstrak dan sulit untuk dibayangkan oleh siswa. Oleh karena itu 
dibutuhkan model pembelajaran dan media pembelajaran yang tepat [1].

Pada hakekatnya pembelajaran fisika mencakup proses, produk, dan sikap. Namun, jika dicermati, pembelajaran fisika cenderung menekankan pada aspek produk, dimana fakta, hukum, dan teori mendapat porsi yang dominan, sehingga aspek proses dan sikap kurang mendapat perhatian. Kondisi seperti ini tentunya tidak sesuai dengan tujuan pembelajaran fisika yaitu untuk menguasai konsep-konsep fisika dan saling keterkaitannya serta mampu menggunakan metode ilmiah yang dilandasi sikap keilmuan untuk memecahkan masalah yang dihadapinya [2].

Pembelajaran fisika merupakan bagian dari sains yang syarat dengan konsep-konsep abstrak. Konsep-konsep yang abstrak ini harus diajarkan dalam waktu yang relatif singkat, sehingga sering kali menjadi kendala bagi guru dalam menyampaikan materi kepada peserta didik yang meyebabkan peserta didik belum optimal dalam memahami konsep yang dijelaskan guru, hal ini tentunya berdampak pada minat belajar peserta didik dalam menerima pelajaran fisika yang menyebabkan rendahnya penguasaan konsep peserta didik untuk menyelesaikan suatu persoalan [3]. Pembelajaran fisika juga seyogyanya mempertimbangkan strategi atau metode pembelajaran yang efektif dan efisien untuk meningkatkan kemampuan berpikir peserta didik [4].

Pada hakikatnya kegiatan guru dalam pembelajaran adalah untuk membelajarkan peserta didik, agar peserta didik dalam kondisi belajar maka perlu diciptakan suasana pembelajaran yang berpusat pada peserta didik (student center) yaitu dengan cara memberikan kesempatan kepada peserta didik untuk aktif dalam membangun pengetahuannya dan mengemukakan ide-ide atau gagasan-gagasannya. Terdapat banyak metode dan media pembelajaran yang dapat dimanfaatkan oleh guru untuk menunjang pembelajaran agar peserta didik ikut berperan aktif dalam proses pembelajaran, misalnya dengan pembelajaran kelompok atau kooperatif. Peserta didik yang tergabung dalam satu kelompok akan saling membantu satu sama lain, peserta didik yang kurang pandai dapat belajar dalam suasana menyenangkan karena banyak teman yang membantu dan memotivasinya, peserta didik yang sebelumnya terbiasa bersikap pasif setelah menggunakan pembelajaran kooperatif akan berpartisipasi secara aktif agar bisa diterima oleh anggota kelompoknya [5].

Berdasarkan hasil observasi yang dilakukan di MAN Lombok Barat yang menerapkan Kurikulum 2013, nilai rata-rata ujian tengah semester ganjil fisika peserta didik kelas XI MIA tahun pelajaran 2017/2018 masih banyak yang berada di bawah Kriteria Ketuntasan Minimal (KKM). Masalah yang sering dihadapi oleh peserta didik dalam proses belajar mengajar yaitu kesulitan peserta didik dalam memahami materi yang diajarkan guru, karena masih banyak guru yang menggunakan model pembelajaran yang belum mengaktifkan seluruh peserta didik, selama ini guru masih menggunakan model pembelajaran konvensional yaitu model pembelajaran yang berpusat pada guru (teacher center). Model pembelajaran seperti ini menyebabkan keterlibatan seluruh peserta didik dalam aktivitas pembelajaran sangat kecil, karena kegiatan pembelajaran didominasi oleh peserta didik yang memiliki kemampuan tinggi sementara yang memiliki kemampuan rendah hanya menonton saja (pasif), hal ini menyebabkan sebagian besar peserta didik terutama yang memiliki kemampuan rendah enggan berpikir, sehingga timbul perasaan jenuh dan bosan dalam mengikuti pelajaran fisika, hal ini kemudian berimplikasi pada rendahnya penguasaan konsep fisika peserta didik. Penguasaan konsep menjadi salah satu aspek dalam mengukur hasil suatu pembelajaran, pentingnya seseorang menguasai suatu konsep adalah agar ia mampu berkomunikasi, mengklasifikasikan ide, gagasan atau peristiwa yang dialaminya dalam kehidupan sehari-hari [6].

Berdasarkan pernyataan tersebut, guru diharapkan untuk bisa memilih model pembelajaran yang tepat dalam setiap proses pembelajaran sesuai dengan situasi dan kondisi peserta didik agar tercapai keberhasilan dalam belajar. Keberhasilan yang dimaksud adalah peserta didik dapat membangun konsep-konsep fisika dengan bahasanya sendiri, mampu mengaplikasikannya dalam kehidupan sehari-hari, serta mampu menyelesaikan masalah-masalah fisika yang ia temukan, untuk mencapai keberhasilan tersebut, diperlukan model pembelajaran yang diharapkan efektif dan menekankan pada penguasaan konsep peserta didik. Salah satu model yang dapat digunakan adalah model pembelajaran CORE,CORE merupakan salah satu tipe dari model pembelajaran kooperatif. Model pembelajaran CORE adalah model pembelajaran yang menggunakan metode diskusi yang dapat mempengaruhi perkembangan pengetahuan dan berpikir reflektif dengan melibatkan peserta didik yang memiliki empat tahapan pengajaran yaitu Connecting, Organizing, Reflecting, dan Extending, peserta didik diharapkan untuk dapat mengkonstruksi pengetahuannya sendiri dengan cara menghubungkan (Connecting) dan mengorganisasikan (Organizing) pengetahuan baru dengan pengetahuan lama kemudian memikirkan kembali konsep yang sedang dipelajari (Reflecting) serta diharapkan peserta didik dapat memperluas pengetahuan mereka selama proses belajar mengajar berlangsung (Extending) [7].

Menurut Budiyanto (2016:50), CORE memiliki beberapa kelebihan diantaranya peserta didik aktif dalam belajar, melatih daya ingat peserta didik tentang suatu konsep/informasi, melatih daya 
pikir kritis peserta didik terhadap suatu masalah, dan memberikan peserta didik pembelajaran yang bermakna. Alasan peneliti memilih model pembelajaran kooperatif tipe CORE adalah karena model CORE memberikan kesempatan kepada peserta didik untuk mencari atau menemukan sendiri makna dari segala sesuatu yang dipelajari, sehingga peserta didik dapat menguasai suatu konsep berdasarkan tingkat perkembangan kognitifnya. Konsep-konsep yang diajarkan kepada peserta didik bukan hanya sekedar hafalan, melainkan konsep tersebut harus dikuasai dan dipahami agar dapat digunakan untuk memecahkan masalah yang dihadapi, selain itu tahapan pembelajaran dengan model CORE menawarkan sebuah proses pembelajaran yang memberi ruang bagi peserta didik untuk berpendapat, mencari solusi serta membangun pengetahuannya sendiri, hal ini memberikan pengalaman yang berbeda sehingga diharapkan bisa meningkatkan kemampuan penguasaan konsep peserta didik. Pernyataan tersebut didukung oleh Humaira dkk [8] bahwa secara umum dengan model pembelajaran CORE peserta didik dapat terbantu dalam melatih komunikasi matematis mereka, hal ini karena dalam pembelajaran guru berusaha membuat peserta didik untuk memikirkan ide-idenya terlebih dahulu sebelum menyepakati sebagai keputusan bersama, begitu pula dengan Hidayat [9] yang mengungkapkan bahwa pembelajaran menggunakan model pembelajaran CORE lebih menekankan pada kemampuan berpikir, peserta didik diarahkan untuk mampu menggunakan kemampuannya dalam memecahkan permasalahan yang diberikan, sehinggapenerapan model pembelajaran CORE (Connecting, Organizing, Reflecting, dan Extending) dapat meningkatkan aktivitas belajar peserta didik. Oleh karena itu, peneliti melakukan penelitian lebih lanjut mengenai model pembelajaran CORE yang dikaitkan dengan penguasaan konsep fisika peserta didik.

\section{METODE PENELITIAN}

Penelitian ini menggunakan jenis penelitian kuasi eksperimen dengan desain penelitian nonequivalentcontrol group. Penelitian ini melibatkan beberapa variabel penelitian sehingga pembaca dapat mengetahui alur dari sebuah penelitian antara lain, variabel bebasyaitu model pembelajaran CORE dan model pembelajaran konvensioanl, variabel terikat yaitu penguasaan konsep fisika, dan variabel kontrol yaitu alokasi waktu, materi ajar, instrumen tes dan cara penilaian sama pada kedua kelas.Populasidalampenelitianiniadalahseluruhpeser tadidikkelas XI MIA di MAN Lombok Barat tahunajaran 2018/2019 yang berjumlah 55 pesertadidik, yakni 28 pesertadidikkelas XI MIA 1 dan 27 pesertadidikkelas XI MIA 2. Teknik pengambilan sampel dalam penelitian ini adalah teknik sampling jenuh, karena semua anggota populasi menjadi sampel. Sampel dalam penelitian ini adalah kelas XI MIA 2 sebagai kelas eksperimen dengan model pembelajaran CORE dan kelas XI MIA 1 sebagai kelas kontrol dengan model pembelajaran konvensional. Instrumen yang digunakan adalah tes penguasaan konsep.

Teknik pengumpulan data berupa tes tertulis berbentuk soal pilihan ganda beralasan. Tes penguasaan konsep berjumlah 25 soal. Indikator yang digunakan dalam tes penguasaan konsep ini mengacu pada taksonomi Bloom revisi ranah kognitif yang dilakukan oleh Krathwohl dan Anderson (2015:99) sebagai berikut. (C1) Mengingat,(C2) Memahami, (C3) Mengaplikasikan, (C4) Menganalisis, (C5) Mengevaluasi, dan (C6) Mencipta. Instrumen tes penguasaan konsep sebelum digunakan harus memenuhi beberapa syarat yaitu uji validitas, reliabilitas, tingkatkesukaran dan dayabedasoal. Uji analisis data menggunakan uji-t polled varians dengan taraf signifikan $5 \%$ dan derajat kebebasan $\left(N_{1}+N_{2}\right)-2$. Data hasil penguasaan konsep yang diperoleh dianalisis dengan uji N-gain untuk mengetahui peningkatan sebelum dan sesudahperlakuanantara keduakelas.

\section{HASIL DAN PEMBAHASAN}

Penelitian ini bertujuan untuk mengetahui apakah terdapat pengaruh model pembelajaran CORE terhadap penguasaan konsep fisika peserta didik. Pada penelitianini, sebelum diberi perlakuan peserta didik terlebih dahulu diberikan tes awal (pretest). Hasil analisis tes awal menunjukkan bahwa tidak terdapat perbedaan yang signifikan antara kemampuan awal peserta didik kelas kontrol maupun kelas eksperimen. Nilai rata-rata yang diperoleh peserta didik dari hasil tes awal tergolong cukup rendah dimana nilai rata-rata kelas kontrol adalah 23,52 dan kelas eksperimen 24,48, hal ini karena kurangnya kemampuan awal peserta didik untuk menghubungkan pengetahuan yang lama dengan pengetahuan baru dan bagaimana mengkonstruksi pengetahuan tersebut, selainitu, peserta didik belum pernah mendapatkan materi yang diujikan, sehingga peserta didik hanya mengandalkan pengetahuan awalnya tadi tentang fisika dan pengalamannya dari kehidupan seharihari untuk menjawab tes yang diberikan.

Hasil tes awal kemudian dianalisis uji prasyarat yaitu uji homogenitas dan uji normalitas. Hasil uji homogenitas tes awal kedua kelas dalam kategori data yang homogen dimana nilai $F_{\text {hitung }}$ lebih kecil dibandingkan $F_{\text {tabel }}$ pada taraf signifikan $5 \%$. Hasiluji normalitas penguasaan konsep pada kedua kelas diperoleh bahwa nilai $\chi^{2}{ }_{\text {hitung }}$ lebih kecil dari $\chi_{\text {tabel }}^{2}$ sehingga dapat disimpulkan bahwa data terdistribusi normal. Hasil uji homogenitas dan normalitas tes awal tersebut menunjukkan bahwa kedua kelas sampe lmemiliki 
kemampuan awal yang sama sebelum diberiperlakuan dan datanyaterdistribusi normal.

Peserta didik kemudian diberi perlakuan berupa pembelajaran fisika dengan menggunakan model pembelajaran CORE untuk kelas eksperimen dan model pembelajaran konvensional untuk kelas kontrol dan dilanjutkan dengan memberikan tesakhir (posttest). Uji prasyarat juga diberlakukan untuk tes akhir dimana hasil uji homogenitas tes akhir kedua kelas sampel adalah homogen, begitupula dengan uji normalitas, kedua kelas sampel dinyatakan terdistribusi normal, karenahasil uji prasyarat tes awal maupun tes akhir kedua kelas sampel termasuk kategori homogen dan terdistribusi normal, maka dapat dilanjutkan untuk menguji hipotesis. Kemampuan rata-rata tesawal dan tes akhir penguasaan konsep kedua kelas dapat dilihat pada Gambar 4.1.

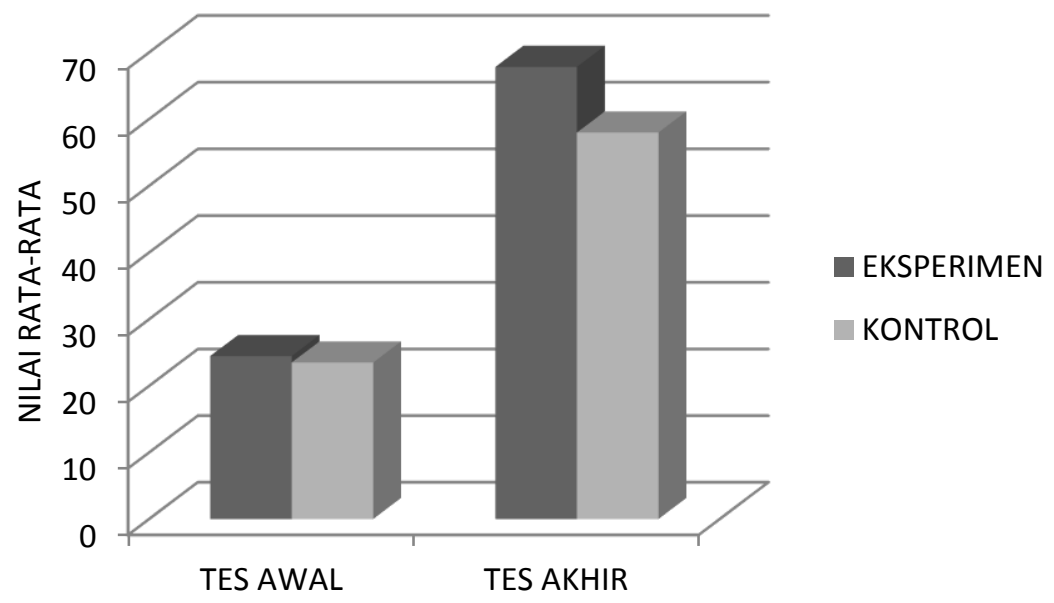

Gambar 4.1 Histogram Kemampuan Rata-rata TesAwal danTesAkhir

Berdasarkan Gambar 4.1 terlihat ada peningkatan rata-rata nilai tes akhir dan tes awal yang telah dilakukan. Peningkatan nilai ini merupakan pengaruh dari perlakuan yang diberikan pada kedua kelas. Pada kelas eksperimen yang diberikan perlakuan berupa model pembelajaran CORE memiliki rata-rata nilai tes akhir 67,84 dan pada kelas kontrol yang diberikan perlakuan berupa model pembelajaran konvensional memiliki ratarata nilai tes akhir 58,00. Meskipun kedua kelas sampel memiliki nilai rata-rata kelas yang meningkat namun, peningkatan pada kelas eksperimen lebih baik dari kelas kontrol.Berdasarkan hasil uji hipotesis yang dilakukan menggunakan uji-t dua sampel bebas (Independent Sample t-test) dengan persamaan t-test polled varians untuk mengetahui ada tidaknya pengaruh dengan membandingkan rata-rata nilai tes akhir dua kelas yang tidak saling berpasangan, maka diperoleh $t_{\text {hitung }}$ lebih besar dari $t_{\text {tabel }}$ pada taraf signifikan $5 \%$, hal ini menunjukkan bahwa terdapat pengaruh model pembelajaran CORE terhadap penguasaan konsep fisika peserta didik kelas XI MAN Lombok Barat, sehingga $\mathrm{H}_{0}$ ditolak dan $\mathrm{H}_{\mathrm{a}}$ diterima.

Hasil penelitian menunjukkan bahwa peserta didik yang diberi perlakuan dengan model pembelajaran CORE mendapatkan nilai yang lebih baik daripada peserta didik yang mendapat perlakuan model pembelajaran konvensional. Perbedaan nilai yang signifikan antara peserta didik yang menggunakan model pembelajaran CORE dengan peserta didik yang menggunakan model pembelajaran konvensional dapat disebabkan perbedaan perlakuan pada langkah-langkah pembelajaran. CORE merupakan model pembelajaran yang menerapkan metode diskusi, dimana melalui pembelajaran CORE diharapkan peserta didik dapat mengkontruksi pengetahuannya sendiri dengan cara menghubungkan (connecting) dan mengorganisasikan (organizing) pengetahuan baru dengan pengetahuan lama kemudian memikirkan kembali konsep yang sedang dipelajari (reflecting) serta diharapkan peserta didik dapat memperluas pengetahuan mereka selama proses belajar mengajar berlangsung (extending) [7]. Selain itu, Shoimin [10] juga menjelaskan bahwa model pembelajaran CORE dapat mengembangkan dan melatih daya ingat peserta didik tentang suatu konsep dalam materi pembelajaran.

Model pembelajaran CORE tentu berbeda dengan model pembelajaran konvensional yang disampaikan dengan menggunakan metode yang biasa dilakukan guru yaitu memberi materi melalui ceramah dan memberikan tugas, hal ini menunjukkan aktifitas guru lebih banyak daripada aktifitas peserta didik dan peserta didik menjadi kurang memahami pelajaran yang mereka pelajari, karena dalam pembelajaran konvensional sangat jarang terdapat kegiatan mengingat kembali dan menghubungkannya kembali dengan materi yang sudah pernah dipelajari sebelumnya serta mengaitkan kembali pada materi yang sedang dipelajarinya, sehingga dalam proses pembelajaran peserta didik hanya pasif menerima materi yang disampaikan oleh guru, adanya perbedaan yang 
signifikan menunjukkan bahwa penerapan model pembelajaran CORE berpengaruh terhadap penguasaan konsep fisika peserta didik, hal ini sejalan dengan penelitian yang dilakukan Muizaddin dan Santoso [11] dimana penggunaan model pembelajaran CORE berpengaruh positif dan signifikan terhadap hasil belajar kognitif peserta didik, pada kelas eksperimen yang menerapkan model pembelajaran CORE terlihat peserta didik lebih aktif untuk berbicara, bertanya, menambahkan hingga menyanggah mengenai materi yang dipelajari saat diskusi, berbeda dengan kelas kontrol dimana peserta didik terlihat lebih pasif karena hanya memperhatikan dan mencatat apa yang diperintahkan pendidik, sehingga peserta didik terbatas untuk lebih aktif di dalam kelas, begitu pula dengan Bahri [12] yang mengungkapkan bahwa pembelajaran menggunakan model pembelajaran CORE efektif dalam meningkatkan keterampilan mengkomunikasikan dan penguasaan konsep peserta didik, hal ini karena model pembelajaran CORE menggunakan metode diskusi sehingga peserta didik terlibat aktif dalam kegiatan pembelajaran, selain itu tahapan-tahapan dalam model pembelajaran CORE disesuaikan dengan taraf perkembangan kognitif peserta didik.

Penguasaan konsep merupakan suatu hal yang komplek sebagai penunjang mempelajari materi fisika. Rendahnya penguasaan konsep akan berpengaruh terhadap kemampuan peserta didik, baik dalam menjawab soal serta menerapkan dalam kehidupan sehari-hari. Tes penguasaan konsep yang digunakan berupa soal pilihan ganda beralasan. Soal pilihan ganda sangat efektif untuk mengukur kemampuan mulai dari kemampuan yang sederhana sampai kemampuan yang rumit seperti kemampuan dalam pengetahuan, pemahaman, dan penggunaan konsep. Soal-soal pilihan ganda juga dapat mengukur kemampuan dalam hal: mengenal istilah, mengenal fakta, mengenal prinsip, mengenal metode dan prosedur, mengidentifikasi penggunaan fakta dan prinsip, menginterpretasikan hubungan sebab akibat, menilai metode dan prosedur [13]. Soal pilihan ganda beralasan berisi soal yang menuntut peserta tes untuk memberikan jawaban atas pertanyaan atau pernyataan yang tercantum dalam pokok soal yang disertai sejumlah kemungkinan jawaban serta alasan yang mendasari dipilihnya jawaban tersebut. Peserta didik diminta untuk memilih jawaban yang benar sekaligus mengemukakan alasan yang mendasari atas jawabannya tersebut. Apabila peserta didik menjawab soal tersebut dengan benar disertai alasan yang tepat, maka dapat dikatakan bahwa penguasaan konsep peserta didik baik. Namun, sebaliknya jika peserta didik menjawab soal dengan benar tapi disertai dengan alasan yang kurang tepat, maka dapat dikatakan bahwa penguasaan konsep peserta didik kurang baik.

Peneliti juga melakukan uji N-gain untuk mengetahui sejauh mana peningkatan yang dialami kedua kelas secara lebih terperinci terkait hubungan nilai kelas kontrol dan kelas eksperimen untuk persentase kenaikan penguasaan konsep baik itu kenaikan pada setiap sub materi maupun kenaikan setiap aspek kognitif. Berdasarkan hasil uji N-gain dapat diketahui penguasaan konsep sebagaian besar sub materi mengalami peningkatan baik pada kelas kontrol maupun kelas eksperimen. Peningkatan kedua kelas dapat dilihat pada gambar 4.2 di bawah ini.

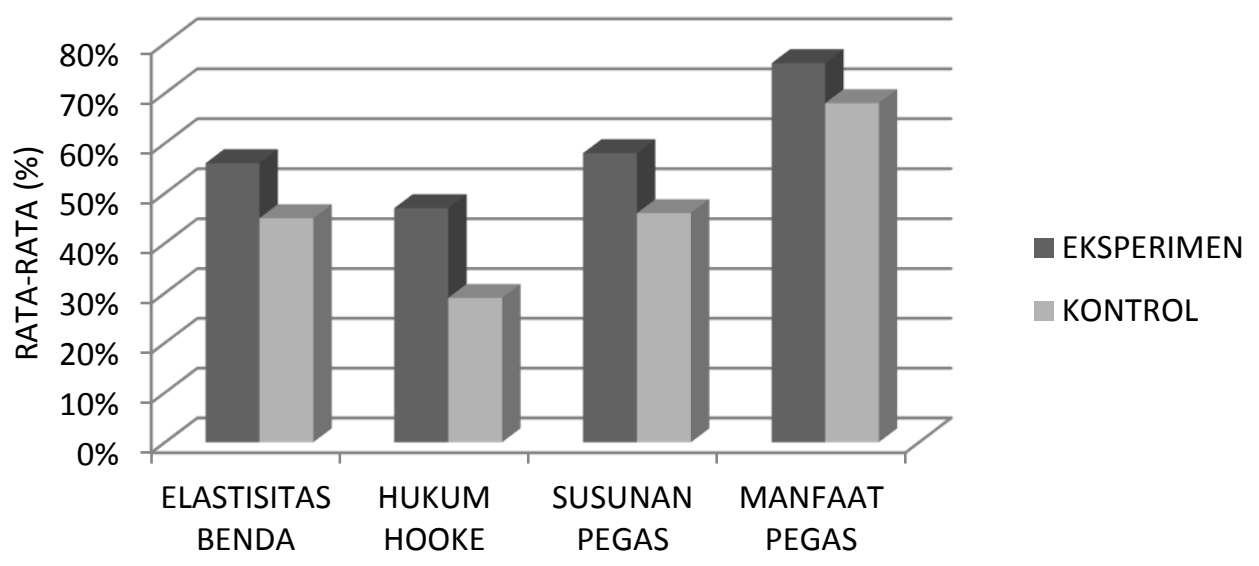

Gambar 4.2 Histogram PerbandinganPeningkatan N-gain Sub Materi

Peningkatan tertinggi terjadi pada materi manfaat pegas dalam kehidupan di kelas eksperimen sedangkan di kelas kontrol tergolong sedang, hal ini karena rasa ingin tahu peserta didik di kelas eksperimen lebih tinggi, meskipun LKPD yang diberikan sama antara kelas kontrol dan kelas eksperimen serta proses pembelajarannya juga sama-sama menggunakan diskusi kelompok. Namun, dalam proses diskusi kelas eksperimen berusaha mencari referensi sebanyak-banyaknya mengenai manfaat pegas baik dari buku maupun internet sehingga pada saat proses persentasi, prinsip kerja alat-alat yang termasuk manfaat pegas dapat terjawab, sedangkan pada kelas kontrol rata-rata tiap 
kelompok kurang mencari referensi prinsip kerja dari alat-alat tersebut, sehingga pemahaman mereka juga kurang, hal ini berkaitan dengan instrumen tes untuk materi manfaat pegas dalam kehidupan tergolong dalam apek kognitif C1 (mengingat) dan C2 (memahami), sehingga butuh pemahaman konsep materi untuk dapat menjawab soal tersebut. Peningkatan sub materi dengan kriteria rendah terdapat pada sub materi hukum hooke di kelas kontrol sedangkan di kelas eksperimen tergolong sedang, hal ini dapat disebabkan peserta didik kelas kontrol tidak terbiasa melakukan diskusi kelompok, karena pada materi hukum hooke kedua kelas melakukan percobaan dan berdiskusi untuk menjawab soal-soal dalam LKPD, selain itu, materi hukum hooke tergolong dalam aspek ranah kognitif C3 (mengaplikasikan), C5 (mengevaluasi), dan C6 (mencipta). Seperti yang sudah dijelaskan sebelumnya bahwa peningkatan kelas kontrol yang tergolong rendah terdapat pada C3 dan C6, sehingga hal ini berkaitan dengan alasan sebelumnya. Analisis peningkatan penguasaan konsep elastisitas dan hukum hoooke pada setiap aspek kognitif dapat dilihat pada gambar 4.3 berikut.

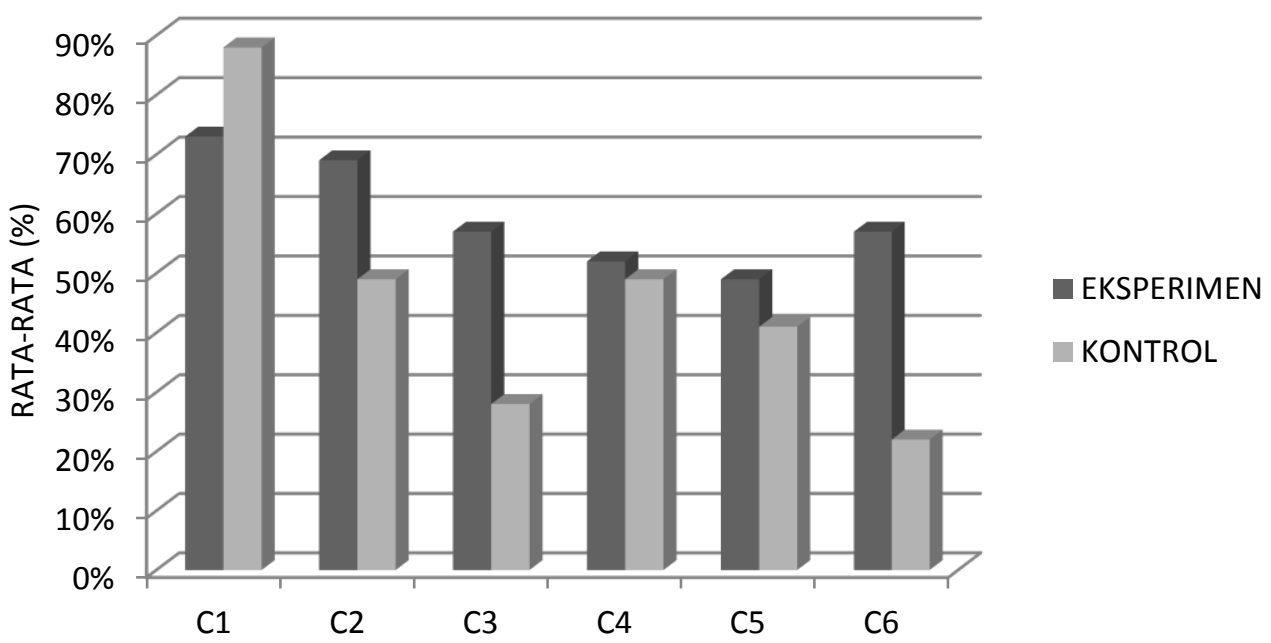

Gambar 4.3 Histogram PerbandinganPeningkatan N-gain AspekKognitif

Berdasarkan Gambar 4.3, perbandingan hasil tes akhir penguasaan konsep yang dikaji dari aspek kognitif menunjukkan secara keseluruhan penguasaan konsep kelas kontrol dan kelas eksperimen sama-sama mengalami peningkatan. Namun, peningkatan kelas eksperimen lebih tinggi dibanding kelas kontrol, dimana pada aspek kognitif C3 dan C6 kelas kontrol mengalami peningkatan yang tergolong rendah sedangkan kelas eksperimen tergolong sedang, hal ini karena pada kelas kontrol penyajian materi yang dilakukan oleh guru kurang mendapat respon dari peserta didik, peserta didik yang aktif di kelas hanya beberapa orang saja, kebanyakan peserta didik hanya mendengarkan atau bersifat pasif, sehingga peningkatan pada kelas kontrol dalam aspek kognitif C3 (mengaplikasikan) dan C6 (mencipta) tergolong rendah, sebaliknya di kelas eksperimen, peserta didik terlibat aktif karena model pembelajaran CORE menerapkan metode diskusi, sehingga memunculkan rasa ingin tahu, peserta didik lebih berani saat menjelaskan di depan kelas, dan lebih bersemangat menggali konsep dari materi elastisitas dan hukum hooke. Peningkatan tertinggi terdapat pada aspek kognitif C1 (mengingat), hal ini disebabkan karena instrumen untuk aspek kognitif ini tergolong mudah dan sebelumnya sudah diberikan dalam bentuk materi, contoh dan latihan soal pada kegiatan pembelajaran.
Berdasarkan teori dan temuan dalam penelitian ini dapat dinyatakan bahwa model pembelajaran CORE mampu membantu peserta didik dalam menguasai konsep baik teori maupun penerapannya dalam kehidupan sehari-hari, hal ini karena model pembelajaran CORE dapat menjadikan peserta didik lebih aktif dalam belajar, terbukti pada saat proses pembelajaran rasa ingin tahu peserta didik lebih tinggi karena untuk dapat berperan aktif, maka peserta didik harus dapat mengingat informasi dan menggunakan pengetahuannya untuk menghubungkan topik yangdidiskusikan, selain itu, model pembelajaran $C O R E$ juga dapat melatih daya ingat peserta didik tentang suatu konsep/informasi, dimana peserta didik mengatur dan mengorganisasikan informasi dari berbagai sumber menjadi suatu pengetahuan baru baik dengan cara meringkas hasil-hasil penting dalam diskusi atau menuliskan langkah-langkah yang menghubungkan antara pengetahuan lama dengan pengetahuan baru yang mereka diskusikan. Peserta didik juga dilatih untuk berpikir reflektif baik sebelum maupun sesudah diskusi agar peserta didik mampu menyelesaikan masalah berbeda namun memiliki dasar konsep yang sama menggunakan pengetahuan lama danpengetahuan baru yang dimiliki, serta memberikan peserta didik pembelajaran yang bermakna, diskusi membantu 
peserta didik memperluas pengetahuannya, diskusi dilakukan untuk memperoleh berbagai macam informasi dari teman-teman dan gurunya sesuai topik serta mencoba untuk menjelaskankembali kepada teman-teman dan guru.

Kendala-kendala yang dialami oleh peneliti khususnya saat melaksanakan pembelajaran di sekolah ialah kurang optimalnya dalam pembimbingan kelompok diskusi peserta didik dan pengelolaan waktu, karena model pembelajaran CORE ini membutuhkan persiapan yang optimal dari guru serta memerlukan banyak waktu, dan juga tidak semua materi pelajaran dapat menggunakan model CORE. Kendala lainnya yaitu tidak terbiasanya peserta didik dalam mengerjakan soalsoal pilihan ganda beralasan. Peserta didik mengalami kesulitan untuk memberikan alasan terkait jawaban yang dipilih karena alokasi waktu untuk menjawab soal pilihan ganda beralasan dengan jumlah 25 soal tergolong kurang, peserta didik harus menyelesaikan soal-soal tersebut dalam waktu 90 menit bahkan kurang karena waktu juga terpakai untuk persiapan sebelum mengerjakan soal, hal ini menyebabkan skor peserta didik berkurang akibat alasan yang diberikan peserta didik kurang tepat dan kekurangan waktu untuk menjawab. Sehingga, nilai rata-rata kedua sampel kurang dari Kriteria Ketuntasan Minimal (KKM). KKM mata pelajaran fisika di MAN Lombok Barat adalah 75,00 sedangkan nilai rata-rata kelas eksperimen sebesar 67,84 dan kelas kontrol sebesar 58,00.

Terlepas dari segala kekurangan dalam penelitian ini, peneliti telah membuktikan bahwa model pembelajaran CORE berpengaruh terhadap penguasaan konsep fisika peserta didik kelas XI MAN Lombok Barat, terbukti dari hasil uji hipotesis yang telah dilakukan bahwa. $t_{\text {hitung }}$ lebih besar dari $t_{\text {tabel }}$ pada tarafsignifikan $5 \%$ yang berarti $\mathrm{H}_{0}$ ditolak dan $\mathrm{H}_{\mathrm{a}}$ diterima. Oleh karenaitu, model pembelajaran CORE dapat menjadi alternatif untuk meningkatkan penguasaan konsep.

\section{KESIMPULAN}

Berdasarkan hasil penelitian, dapat disimpulkan terdapat pengaruh model pembelajaran CORE terhadap penguasaan konsep fisika peserta didik kelas XI MAN Lombok Barat.

\section{DAFTAR PUSTAKA}

[1] Sani, dkk. 2018. Pengaruh Model Pembelajaran Direct Instruction Dengan Media Macromedia Flash Terhadap Hasil Belajar Fisika Kelas Xi Sman 1 Kopang. Jurnal Pijar MIPA Vol.13 No.1 hal. 13-18.

[2] Gunawan, Harjono A., Sahidu H., \& Sutrio. 2011. Penggunaan Multimedia Interaktif dalam Pembelajaran Fisika dan Implikasinya pada
Penguasaan Konsep Mahasiswa. Jurnal Pijar MIPA, IX (1): 15-19.

[3] Husein, S., Herayanti, L., \& Gunawan. 2015. Pengaruh Penggunaan Multimedia Interaktif terhadap Penguasaan Konsep dan Keterampilan Berpikir Kritis Siswa pada Materi Suhu dan Kalor. Jurnal Pendidikan Fisika dan Teknologi, I (3): 221-225.

[4] Latifa, B.R.A, Verawati, N.N.S.P., \& Harjono, A. 2017. Pengaruh Model Learning Cycle 5E (Engage, Explore, Explain, Elaboration, \& Evaluate) terhadap Kemampuan Berpikir Kritis Peserta Didik Kelas X MAN 1 Mataram. Jurnal Pendidikan Fisika dan Teknologi. III (1): 61 67).

[5] Wena, M. 2014. Strategi Pembelajaran Inovatif Kontemporer Suatu Tinjauan Konseptual Operasional. BumiAksara: Jakarta.

[6] Suranti, N. M. Y., Gunawan, \&Sahidu, H. 2016. Pengaruh Model Project Based Learning Berbantuan Media Virtual terhadap Penguasaan Konsep Peserta Didik pada Materi Alat-alat Optik. Jurnal Pendidikan Fisika dan Teknologi, II (2): 73-79.

[7] Calfee, R.C. \& Miller, R.G. 2004. Making Thinking Visible: A Method to Encourage Science Writing in Upper Elementary Grades. National Science Teachers Association. University of California, Riverside, 42 (3): 2025.

[8] Humaira, F.A., Suherman, \&Jazwinarti. 2014. Penerapan Model PembelajaranCORE pada PembelajaranMatematikaSiswa Kelas X SMAN 9 Padang. Jurnal Pendidikan Matematika, III (1): 31-37.

[9] Hidayat, Y.M., Lesmanawati, R.I., \&Maknun, D. 2014. Penerapan Model PembelajaranCORE (Connecting, Organizing, Reflecting, dan Extending) terhadapPeningkatan Hasil BelajarSiswa pada KonsepEkosistem di Kelas X SMAN 1 Ciwaringin. Scientiae Educatia, III (2): $111-124$.

[10] Shoimin, A. $2014 . \quad$ Model PembelajaranInovatifdalamKurikulum 2013. Yogyakarta: Ar-Ruzz Media.

[11] Muizaddin, R. \&Santoso, B. 2016. Model PembelajaranCOREsebagaiSaranadalamMenin gkatkan Hasil BelajarSiswa. Jurnal Pendidikan ManajemenPerkantoran, I (1): 235-243.

[12] Bahri, A., Kadaritna, N., \&Efkar, T. 2014. EvektifitasPembelajaranCORE

dalamMeningkatkanKeterampilanMengkomun ikasikan dan PenguasaanKonsepKelarutan dan KSP. Jurnal Pendidikan dan Pembelajaran Kimia, III (2): 1-11.

[13] Surapranata, S. 2004. Panduan PenulisanSoalSoal. Bandung: PT. RemajaRosdakarya

[14] Budiyanto, M.A.K. 2016. Sintaks 45 MetodePembelajarandalam Student Centered Learning (SCL). Malang: UMM Press. 
J. Pijar MIPA, Vol. 14 No.3, September 2019:176-183

ISSN 1907-1744 (Cetak)

DOI: http://dx.doi.org/10.29303/jpm.v14i3.974

ISSN 2460-1500 (Online)

[15] Krathwohl, D.R. \& Anderson, L.W. 2015.

Pembelajaran, Pengajaran, dan Asesmen.

Yogyakarta: PustakaPelajar. 